\title{
Pre-Marital Screening for Thalassaemia - Legal, Social and Technical Obstacles
}

\author{
Zeeshan Hussain*, Saqib Ansari \\ National Institute of Blood Disease \& Bone Marrow Transplantation, Karachi, Pakistan.
}

Pre-marital or carrier screening before marriage conventionally refers to detect defective or diseased genes causing autosomal or $\mathrm{X}$-linked recessive genetic diseases in the offspring, having significant morbidity and reduced life expectancy in the progeny. Despite miraculous advancements in medical sciences, most of the genetic disorders still remain a challenge for the medical scientist in term of cure. Lifelong supportive treatment is the only hope for the patients in such diseases. This form of treatment puts a huge financial and social burden on the individuals as well as on health care system. Thalassaemia makes the most highlighted component of the list of these lethal genetic disorders and its prevention through pre-marital screening is now the matter of concern for most of the country it prevails in. Thalassaemia is caused by defective synthesis of globin chains (either alpha or beta) resulting in reduced haemoglobin production with interestingly variable phenotype from lifelong transfusion dependency to asymptomatic individuals [1]. Morbidity and mortality due to thalassaemia still claims a major share worldwide; unfortunately has no universally available cure [2]. Bone marrow transplant provides a curative option for the disease but high cost, suitable donor (HLA Matched), procedure related complications ( e.g. infections) and relapsed are still major obstacles down the road [3-6].

Prevention of thalassaemia remains only viable option to control the disease, and a multi-prong strategy needs to be devised to achieve the targets. Fortunately, with the advent of DNA testing of such diseases now it looks feasible to cope up aforementioned challenges by pre-marital/post-marital screening programs. Thalassaemias were conventionally considered a disease of tropic and sub-tropics but, now it is prevalent in other part of the world mainly due to migration [7, 8]. WHO recommended establishing services for screening of haemoglobinopathies but it requires incorporation of genetic approaches in the primary health care systems and training of the health personnel [8]. Screening of haemoglobinopathies was initiated in the western world in 1970s and started with screening of sickle cell disorder in Virginia, USA [9]. Later, in 1975 pre-marital screening was initiated in Latium, Italy as part of school screening program [10]. Gradually, national wide screening programs were initiated in Canada, Cyprus, Greece, Italy and the UK during the 1970s, proven success

*Address correspondence to this author at the National Institute of Blood

Disease \& Bone Marrow Transplantation, Karachi, Pakistan.

E-mail: zeeshan.share@gmail.com,zeeshan79ha@hotmail.com was noted in these countries [11]. Till 2009, countries having pre-marital screening program for thalassaemia or other haemoglobinopathies, either mandatory or voluntary includes Italy, Greece, Jordan, Iran, UAE, Saudi Arab, Portugal, Tunisia, Egypt, Spain, Bahrain, Turkey, Cyprus, China, Taiwan, Brazil, Palestine, India, Singapore, Maldives, Indonesia and Thailand [12].

Technically the screening of thalassaemia involves Complete Blood Counts (CBC) may be complemented by Single Tube Osmotic Fragility Test (SOFT) and later confirmatory testing by $\mathrm{Hb}$ Electrophoresis \& DNA analysis [13-15]. Talking specifically about Beta Thalassaemia, individuals having single defective or mutated globin gene are known as thalassaemia minor or carriers. There are $25 \%$ chances of having an affected child at every pregnancy if both parents are thalassaemia minor.

Estimated carrier rate of beta thalassaemia in Pakistan is about $5-7 \%$ in total population, higher in some northern areas and in communities where inter-community marriages are common $[13,16,17]$. In Pakistan, concrete endeavors mainly by non-governmental organizations regarding pre-marital screening of thalassaemia were figured out after 2010, whilst Khyber-Pakhtunkhwa (K-P) provincial assembly passed the very first bill regarding pre-marriage screening of thalassaemia followed by Sindh and Punjab provinces [18]. Out of four provinces and three federally administered region (Azad Kashmir, Gilgit Baltistan and FATA) only three aforesaid provinces have mandatory pre-marital screening de jure. After 18th amendment of the constitution of Pakistan health is totally a provincial subject [19]. Now it is the sole responsibility of the provinces to have their own pre-marital thalassaemia screening program. But practically little has been done and a lot more to go. According to 2017 census the total population of the country is approximately over 200 millions [19]. To screen carriers from such a huge number of individuals, a thoroughly planned strategy is desirable. Our neighbor countries with relatively better thalassaemia pre-marital screening programs are Saudi Arab, Iran and UAE $[20,21]$. They have started their programs far earlier than us and perusal of their strategy and obstacles they faced, it looks obvious that relatively they are facing same social problems like us, though have a better financial backup hence a better healthcare framework.

www.njhsciences.com 
Keeping in view, the current scenario of Pakistan in specific and other Middle Eastern and South Asian countries in general, we discuss one by one all the social, technical and legal issues related to pre-marital thalassaemia screening. In the end some recommendations will be proposed to overcome the problems.

1. Level of awareness among masses regarding the disease being targeted is the key to success of such screening programs. Until and unless people are not enough sentient regarding the grave issue they are going to have if remain unscreened, they will not voluntarily come forward to get them screened. Urban cities have a better outlook regarding screening mainly due to higher level of education and media access. But majority of the population which still resides in rural areas and belongs to low socioeconomic status is still far apart from such screening programs.

2. Lack of enough legal cover for the support of pre-marital screening is still missing, though provincial governments have passed law regarding pre-marital screening but de facto no such machinery exist for the implementation of the law. The act itself has ambiguity and lacks detailing regarding punishment/penalization to those violates the mandatory screening. Further it also lacks how to prosecute the individuals involved in the process of marriage registration without ensuring pre-marriage thalassaemia screening. Multi-level mandatory screening for thalassaemia e.g. at time of college admission, at the time of eligibility for having National Identity Card etc. should also be made. The act is still meager in terms of comprehensive legal coverage of the screening program.

(The Sindh Prevention and Control of Thalassaemia ACT, 2013 may be accessed at

http://www.pas.gov.pk/uploads/acts/Sindh\%20Act $\% 20$ No . I\%20of\%202014.pdf)

3. The social norms of our society also make us avoid any pre-marital testing specially in case of female. Our culture still lacks such level of awareness that individuals stigmatized with some disease could be accepted easily. Furthermore close community and consanguineous marriages are still very much common and almost practiced religiously.

4. Last not the least, a complete technical infrastructure that makes pre-marital screening practicable is needed. It includes enough genetic counselors, laboratory facilities, technical staff and all other outreach services accessible to all the people. Further in a country like Pakistan mandatory type of screenings must be free of cost so that people may be incentivize through free testing.
All these problems need micro and macro level management. In a few words we have to work on many fronts at the same time. Mass awareness campaigns regarding thalassaemia must be started immediately specially in rural areas. Rectify the existing laws and draft further laws to cover all the aspects of this mandatory screening. Financial backup for the program is the utmost part as provision of all the technical facilities depends on it. And lastly, discourage strict adherence of consanguineous and close community marriages.

\section{CONFLICT OF INTEREST}

Declared None.

\section{ACKNOWLEDGEMENTS}

Declared None.

\section{REFERENCES}

[1] Galanello R, Origa R. Beta-thalassemia. Orphanet J Rare Dis 2010; 5(1): 11. DOI: 10.1186/1750-1172-5-11

[2] dos Santos DG, Zidova Z, Mikhael M, Hamdi A, Horvathova M, Ponka P. Pathophysiology and treatment of beta-thalassemia: Investigations of heme oxygenase 1 and its inhibitors. Am Soc Hematol 2015; 126: 3373.

[3] Shamsi T, Hashmi K, Adil S, et al. The stem cell transplant program in Pakistan-the first decade. Bone Marrow Transplant 2008; 42(S1): S114. DOI: 10.1038/bmt.2008.137

[4] Anwar M. Bone marrow transplant in Pakistan: Indications and economics. J Coll Physicians Surg 2003; 13(9): 549-51.

[5] https://www.infoplease.com/country/pakistan [Internet]. [cited 14/05/2018]. Available from:

https://www.infoplease.com/country/pakistan.

[6] http://www.who.int/countries/pak/en/ [Internet]. [cited 14/05/2018]. Available from: http://www.who.int/countries/pak/en/.

[7] Weatherall D, Clegg JB. Inherited haemoglobin disorders: An increasing global health problem. Bull World Health Org 2001; 79: 704-12.

[8] Modell B, Darlison M. Global epidemiology of haemoglobin disorders and derived service indicators. Bull World Health Org 2008; 86(6): 480-7. DOI: 10.2471/BLT.06.036673

[9] Neal-Cooper F, Scott RB. Genetic counseling in sickle cell anemia: Experiences with couples at risk. Public Health Rep 1988; 103(2): 174.

[10] Silvestroni E, Bianco I, Graziani B, Carboni C, D'arca S. First premarital screening of thalassaemia carriers in intermediate schools in Latium. J Med Genet 1978; 15(3): 202-7. DOI: 10.1136/jmg.15.3.202 
[11] Tosun F, Bilgin A, Kizilok A, Arpaci A, Yüregir G. Five-year evaluation of premarital screening program for hemoglobinopathies in the province of Mersin, Turkey. Turk J Hematol 2006; 23(2): 84-9.

[12] Alswaidi FM, O'brien SJ. Premarital screening programmes for haemoglobinopathies, HIV and hepatitis viruses: Review and factors affecting their success. J Med Screening 2009; 16(1): 22-8. DOI: $10.1258 / \mathrm{jms} .2008 .008029$

[13] Ahmed S, Saleem M, Modell B, Petrou M. Screening extended families for genetic hemoglobin disorders in Pakistan. New Engl J Med 2002; 347(15): 1162-8. DOI: 10.1056/NEJMsa013234

[14] Capua A. The montreal thalassemia screening program: Response of the high school students. Ann NY Acad Sci 1998; 850(1): 401-3. DOI: 10.1111/j.1749-6632.1998.tb10503.x

[15] Kattamis C, Efremov G, Pootrakul S. Effectiveness of one tube osmotic fragility screening in detecting beta-thalassaemia trait. J Med Genet 1981; 18(4): 266-70. DOI: 10.1136/jmg.18.4.266

[16] Khattak MF, Saleem M. Prevalence of heterozygous b-thalassaemia in the northern areas of Pakistan. J Pak Med
Assoc 1992; 42(1): 32-4.

[17] Ansari SH, Shamsi TS, Ashraf M, et al. Molecular epidemiology of $\beta$-thalassemia in Pakistan: Far reaching implications. Int J Mol Epidemiol Genet 2011; 2(4): 403.

[18] Provinces Asked to Implement Thalassaemia Law [Internet]. 2015 [cited 15/5/2015]. Available from: https://www.dawn.com/news/1180896.

[19] Pakistan Population (live) [Internet]. [cited 15/5/2018]. Available from: http://www.worldometers.info/world-population/pakistan-pop ulation/.

[20] Samavat A, Modell B. Iranian national thalassaemia screening programme. BMJ 2004; 329(7475): 1134-7.

DOI: $10.1136 / \mathrm{bmj} .329 .7475 .1134$

[21] Awareness Drive Against Genetic Diseases Challenges Social Norms [Internet]. Available from:

http://www.saudigazette.com.sa/article/524802/SAUDI-ARA BIA/Awareness-drive-against-genetic-diseases-challenges-so cial-norms. 